\title{
Kernos
}

Revue internationale et pluridisciplinaire de religion grecque antique

29 | 2016

Varia

\section{The Oxford Handbook of Ancient Greek Religion}

\section{Scott Scullion}

(2) OpenEdition

Journals

Electronic version

URL: http://journals.openedition.org/kernos/2415

DOI: $10.4000 /$ kernos. 2415

ISSN: 2034-7871

\section{Publisher}

Centre international d'étude de la religion grecque antique

\section{Printed version}

Date of publication: 1 October 2016

Number of pages: 415-422

ISSN: 0776-3824

Electronic reference

Scott Scullion, «The Oxford Handbook of Ancient Greek Religion », Kernos [Online], 29 | 2016, Online since 01 October 2016, connection on 17 November 2020. URL : http://journals.openedition.org/ kernos/2415; DOI : https://doi.org/10.4000/kernos.2415

This text was automatically generated on 17 November 2020.

Kernos 


\title{
The Oxford Handbook of Ancient Greek Religion
}

\author{
Scott Scullion
}

\section{REFERENCES}

Esther EIDINOW, Julia KINDT (éd.), The Oxford Handbook of Ancient Greek Religion, Oxford, Oxford University Press, 2015. 1 vol. 17,5 × 25 cm, xxii+708 p. ISBN : 978-0-19-964203-8.

1 As a guide to the study of Greek religion for scholars and graduate students, who are the target audience of the Oxford "Handbook" series, the helpful and up-to-date volume edited by Eidinow and Kindt will give good service. The editors state a programme for the volume in their introduction (p. 1-2): the focus is to be on problems and debates; varying approaches and methodologies and the history of scholarship are to be taken into account; and the "diversity of relationships between mortals and the supernatural" is to be explored in the full range of their contexts and in terms both of the physical (such as ritual) and the metaphysical ("discourses as evidence for beliefs"). Contributors were also encouraged to explore "unofficial" aspects of Greek religion such as magic which have on the editors' view been marginalised under the influence in recent years of the "polis religion" paradigm of Christiane Sourvinou-Inwood; in this respect the project of co-editor Kindt's Rethinking Greek Religion (Cambridge, 2012) is taken up in the handbook. On the whole the contributors have carried through the editors' programme successfully, but of course the fourty-three chapters vary in their approach; some contributors have, for example, found the 'polis religion' perspective indispensable. Some chapters are so focused on problems and debates that Realien get rather short shrift, and in such cases inexpert readers will need to seek an introduction to the fundamentals elsewhere before being able to benefit fully from the orientation to current scholarly debate provided here. In this respect, Blackwell's A Companion to Greek Religion edited by Daniel Ogden (Oxford, 2007) - which also included magic (and to which the reviewer contributed a chapter) - is sometimes more helpful, and those new to the subject would be well advised to consult both. As an introductory work, however, 
I would still unhesitatingly recommend Walter Burkert's Griechische Religion der archaischen und klassischen Epoche (Stuttgart, 1977² $2011^{2}$ ), a masterpiece of learning and concision, rich in detail and conceptually exciting, which has been translated into several languages. Eidenow and Kindt have planned the organisation and coverage of their volume carefully and well, though pollution and purity in particular deserve more attention than they get here. No collective volume rivals Burkert for comprehensiveness and quality of coverage, but as a guide to trends and issues in the post-Burkert study of Greek religion the new handbook fills an important need.

The volume has in general been well edited and proofread, but the English of some chapters has been inadequately revised (see below), and parenthetic references to monographs without specification of the relevant pages are unhelpfully common.

It is impossible to do justice to the contents of such a huge volume even in a relatively lengthy review. In what follows I mention and briefly evaluate every chapter, commenting in greater detail when it strikes me that those (relatively) new to the subject may be misled or should be specially encouraged to read sceptically, or when a chapter seems to me to fall short of meeting their needs. Given the enormously wide scope of the book, my responses to it will inevitably reflect the limitations of my own learning and interests.

The first section of the book, "What is Ancient Greek Religion?", begins with Robin Osborne's chapter "Unity vs. Diversity". He rightly emphasises diversity, but sometimes exaggerates. The claim, for example, that "there is no reason to think that there was, in fact, a paradigmatic sacrificial ritual" (p. 14) seems a misleading half-truth: inscribed sacrificial calendars regularly assume a standard form of sacrifice, specifying only variations on the norm or distinct sacrificial procedures such as holocaust. Osborne's observation that the sacrificial festival Laphria "breaks all the normal rules" is sound, but its validity - and the demonstrative eccentricity of the rite itself - depends precisely on the existence of the norm. Likewise, the ash altars of Olympia and Mt Lykaion represent a demonstrative variation on normal altars - perhaps in a bid for primaeval status - rather than, as Osborne suggests, the absence of an altar (p. 15). But Osborne's chapter is a lively and provocative introduction to this centrally important topic.

5 Thomas Harrison's "Belief vs. Practice" argues for a need "to accept the sphere of religious 'belief' as a more significant aspect in the study of Greek religious experience" (p. 27) and touches interestingly but briefly - and without much reference to specific Greek examples - on a wide variety of approaches to the definition of belief. Harrison looks for an emancipation "from the long legacy of the study of Greek religion, with its false choice of ritual and belief" (p. 27). He cites with approval Naerebout's claim that "there is no ritual without belief" (p. 24), but the triumph ceremony of greylag geese and the ordering, comforting ritualisations of routine domesticity - rituals that need express nothing more, and nothing less fundamental, than safety and belonging - are among the phenomena that cast doubt on that very strong claim. It is surely right that the matter of "belief" needs attention, but the notion of "false choice" risks replacing one excessively hard-and-fast assumption with another.

In her chapter "Old vs. New", Emily Kearns fruitfully explores the dynamics of this polarity rather than focusing on the polar extremes. She engages consistently and subtly with relevant Greek evidence, and the chapter ends with an illuminating 
discussion of persistence and change, and of the representation of the new as renewal, in connection with the cults of Andania in Messenia.

7 The final chapter in the opening section, "Many vs. One", co-authored by Vinciane Pirenne-Delforge and Gabriella Pironti, is a splendid introduction to the problem of polytheism. It begins with a discussion of the origins and history of the term, provides a brief but incisive orientation to scholarly currents in the study of polytheism, and concludes with case studies of the Moirai and of Hera which well illustrate both the issues at stake and the authors' network-based approach to capturing and relating adequately both individual divine personality and interrelatedness within pantheons. This is a very promising approach, but can in its own way be reductive; it seems to me, for example, that the general political role of the Moirai in Aeschylus' Oresteia - in whose final lines Zeus and Moira come together - goes far beyond the "correct distribution of births and deaths within the community" extrapolated from their routine cultic concerns (p. 43).

8 "Types of Evidence" are discussed in the six papers of Part II of the volume, which deal in turn with visual evidence (Milette Gaifman), literary prose (Hannah Willey), poetry (Renaud Gagné), epigraphy (Claire Taylor), material evidence (Caitlín E. Barrett) and papyrology (David Martinez).

9 Gaifman discusses the use of visual material sensibly enough, but the chapter can be repetitive and tends to belabour straightforward points. In her discussion of a relief from the Piraeus which depicts a woman and child interacting with a god, Gaifman employs a methodological assumption which seems simplistic and potentially misleading. She claims that the image is "irrefutable proof that at least the commissioner of this marble object envisioned such a remarkable religious experience" as "the epiphany experienced by the woman and the boy" (p. 59, cf. p. 61), but Gaifman has herself emphasised that images have their own generic and authorial particularities (p.53), and the capacity of the sculptor (and of Greeks in general) to imagine such an encounter between mortal and god and to find (symbolic) meaning in it need not depend on a belief that such things really happened in the contemporary world. I also know of no basis for Gaifman's undocumented claim that "animal sacrifice required the participation of more than one person" (p. 53). The chapter ends strongly, however, with a good discussion of Samian coins depicting the temple and image of Hera.

10 Willey's discussion of prose sources also tends to elaborate uncontroversial points; one would be hard pressed to cite recent work of any significance that employs or defends the kind of naïve reading on which she lavishes so much perfectly valid but unnecessary refutation. Willey rightly follows the lead of Pirenne-Delforge's important book on Pausanias, but there is otherwise a rather parochial feel to her chapter: every other citation is of scholarship in English, which in the case of Herodotus means e.g. that the important work of Walter Burkert (developed by the reviewer in the Cambridge Companion to Herodotus) is ignored, as is highly relevant work in English by Rosalind Thomas. Despite these shortcomings, however, the chapter's intelligent summary of and comment on some important recent work will be very useful to the book's intended audience.

11 At the heart of Gagné's chapter on poetry is a splendid, subtle reading of the Homeric Hymn to Apollo which has especially important things to say about the negotiation of the contrast between Panhellenic and epichoric. Gagné also offers what seems to me a very 
fair-minded discussion of the relationship between tragedy and religion (p.93-94), though the question of the relationship between poetry and religion is perhaps rather more open than he allows. Speaking insistently of poetry as activating "religious imagination" or "religious exploration" rather than simple (general, socio-cultural including religious) imagination and exploration is surely to load the dice by begging the open question whether all Greek genres and authors and works, or all (members of all) Greek audiences, focus primarily on religious and only secondarily on any other cultural matters. Gagné's regular formulation - and that of very many other scholars, of course - seems to involve the highly universalising assumption that Greek culture is primarily a religious culture, that Greeks perceived and understood things fundamentally and first of all in religious terms, that all the imaginings and explorations Greek literature expresses and prompts can comfortably be classified under the single rubric "religious". Of certain Greek writers (Hesiod, Aeschylus, Xenophon) this would seem to me - with important qualifications - not untrue, but of most others, from Homer onwards, it seems at best misleading and at worst false.

Taylor's chapter on inscriptions is a good survey with very helpful bibliography of recent studies of various aspects of epigraphic practice: monumentality and authority, commemoration and devotion, connectivity. Various interesting and important considerations regarding our use of inscriptions are raised and valid cautions against naïve use of epigraphical evidence given, but one misses a case study or two giving positive illustration of the author's notion of what we can learn from inscriptions.

Barrett's chapter on material evidence is an equally wide-ranging and welldocumented but pithier and more incisive account of current issues and trends, and it includes a neat, well-chosen case study of two terracotta figurines which both picks up on programmatic themes of the volume and simply but effectively models positive ways forward.

Martinez's excellent chapter on papyrology concludes Part II. The discussion is based on a very well-chosen set of case studies - a documentary papyrus concerning religious matters and Orphic and magical papyri - and very effectively allies general considerations and precepts to the exegesis of specific texts. Martinez provides rich vindication of the editors' conviction that 'magical' material is essential to an adequate understanding of Greek religion.

Part III, "Myths? Contexts and Representations" consists of chapters by Richard Martin on "Epic", Tanja S. Scheer on "Art and Imagery", Claude Calame on "Drama", Robert Fowler on "History" and Rick Benitez and Harold Tarrant on "Philosophy". Martin explores the relationship between epic and cult, emphasising that ritual material in Homer "must be interpreted, first of all, as part of a self-contained poetic imaginary, and only later as a source to be aligned with other religious discourses in Greek life" (p. 152). This seems to me a sound approach - its key justification is that the first mode of interpretation always works - but for "self-contained" it would surely be preferable to say "autonomous" or "independent". Some of Martin's 'aligning' interpretations can, however, seem rather forced. Observing that prayers in the Iliad are generally fulfilled, and having explained the literary advantages of this very satisfactorily, he goes on to claim that "the totality of such recurrent plot events... crystallizes into a form of belief. Epic thereby regulates the religious imagination" (p.158), which is no more than arbitrary assertion, a statement of how he thinks it must have been. Speaking of the epic poet's claim to divine inspiration, Martin says that "we should take this framing 
conceit at face value" (p. 160, cf. p. 162), which is equally arbitrary. The absence of any compelling argument for such conclusions, alongside the consistent adequacy of poetic explanations, is among the reasons some of us are reluctant to conclude that epic poetry regulates Greek religious belief or that the poet's claim to inspiration is anything more than a traditional conceit.

In her chapter, Scheer discusses (primarily Athenian) divine images, reflecting on their role in childhood experience, their various types, locations, and significance, and on the question of hierarchy among them. Our evidence for such matters is vanishingly thin, and the chapter therefore consists largely of interesting but untestable speculation. There is more, but sometimes conflicting evidence for the appearance of the primary images of Athena on the Acropolis in Athens, and Scheer discusses this in great detail.

Calame argues that Greek drama is a ritual act, a view which I have myself opposed, and which e.g. Gagné in his contribution to this volume (p. 93) and many other scholars do not accept. Those sympathetic to the tragedy-as-ritual approach will welcome on its own terms Calame's application of it to Euripides' Ion, Iphigenia in Tauris, and Erechtheus; others will appreciate it in different terms as a study of Athenian and cultic/choral resonances in the plays which are no less present - and, one may feel, play a subtler (allusive, ironic) role in the dramatic and thematic economy of the plays - if they are not ritual "choral projections" which unequivocally shift the audience into an insistently cultic here and now.

Fowler's chapter on history is outstanding, one of the highlights of the volume, wellwritten, witty and wise: “...there will be cases where one cannot be sure what one is dealing with. This is particularly true for one's own myths; they always seem like history" (p. 197). The chapter begins with a concise but splendidly incisive account of the relationship, from ancient to modern, between myth and history, and proceeds to illuminating case studies of Herodotos and Phanodemos. Fowler is among those who in recent years have developed a nuanced view of Herodotos as sceptical about myth and lore concerning the gods, in part through careful observation of the distinction between what the historian recounts and what he says in his own voice. Within the brief span of his chapter he says a great deal of fundamental importance on this subject, and also on the "nonchalance about aetiological conformity in a ritual context" (p. 206) which he finds in Phanodemos and the Atthidographic tradition. The chapter is strongly recommended not only to students of Greek religion but to classicists in general.

Benitez and Tarrant begin by clearing the ground of what they argue are distortions and false dichotomies in our sense of the relationship between religion and philosophy based ultimately on loaded perspectives and classifications of Aristotle. This is followed by case studies exploring the nature and complications of the relationship in Xenophanes, Plato, and early imperial Platonism and Pythagoreanism. The chapter is clear, helpful, and (so far as my inexpert judgement goes) persuasive.

With Parts IV to VIII of the volume we come to the traditionally central topics of Greek religion as practised: locations and communities (IV, "Where?"), religious authority and control (V, "How?"), divinities of all kinds (VI, "Who?"), prayer, sacrifice, divination and healing (VII, "What?"), and lifecycle rituals, festivals and calendars, the afterlife (VIII, “When?"). 
21 Michael Scott discusses in general terms and in three case studies the attempt in recent decades to move beyond a traditional focus on the static monumentality of temples and sanctuaries by situating them in their proper contexts: their locations, the various activities that took place in them, and "the experience of sanctuary space" (p. 229). The chapter is a good survey and includes a very helpful bibliography, but in the first case study practice falls short of precept. Scott's discussion of the Samian Heraion is closely based on a paper by Helmut Kyrieleis, whose already problematic remarks on the absence of thighbones among the faunal "debris from feasts" are further garbled by Scott, who represents this as an indication that "the thigh bones (normally a particular delicacy to eat) were most likely, as part of the ritual in this particular sanctuary, burnt as an offering to the gods" (p. 231). This is the first bad blunder I have noticed in the volume, and inexpert readers should beware: one does not of course eat bones, and their absence from the faunal remains does not mean that the meat of the thighs was burnt but rather that it was either cooked and eaten at the sacrifical banquet or given as a priestly prerogative, it being normal sacrificial practice throughout the Greek world (with an aition at Hesiod, Theogony 535-557) to cut out the thighbones from the meat, wrap them in fat, and burn them on the altar as the god's portion (see Gunnel EKROTH, "Thighs or tails?", in P. BRULÉ (ed.), La Norme en matière religieuse en Grèce ancienne, Liège, 2009 [Kernos, suppl. 21], p. 125-151, especially p. 127-128). What Scott intends as an illustration of distinctive local ritual is in fact the most common of cultic practices, which illustrates precisely the kind of gulf between sub-fields that Scott's chapter and the trend of research it represents rightly and laudably aims to bridge and there might very easily be equally fundamental errors in the volume which I have

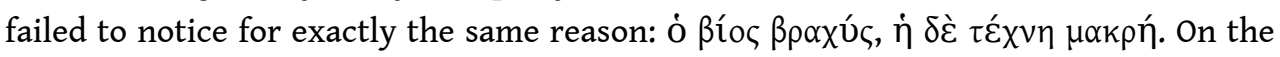
whole, though, Scott's case studies are well-chosen and instructive, especially the last on the temples of Egyptian gods on Delos and what they can tell us about the gods' developing presence on the island over time.

Matthew Dillon's chapter on households, families and women is expertly done: a wellconceived, involving discussion which deftly employs both material and written evidence, it covers the essentials admirably and is recommended enthusiastically. So too is the chapter by Kostas Vlassopoulos, who takes on the mammoth subject of "Religion in Communities" and builds his discussion around the volume's programmatic theme of the "misleading polarity between the religion of the polis, which serves communal cohesion, and religious aspects and practices which cannot be easily accommodated within this scheme" (p. 257). Vlassopoulos's well-documented treatment is sensible and balanced, richly informative, and supported firmly throughout by appropriate evidence. Christy Constantakopoulou's chapter on regional religious groups, amphictionies, and other leagues follows naturally on Vlassopoulos's, shifting the focus to religious communities and networks beyond the confines of the polis. This is another admirable treatment, equally sensible, informative and welldocumented, and culminating in fine case studies of Delos and Samothrace.

Michael Flower's chapter on religious expertise, the first in Part V, begins with Plutarch's account of how in their dreams the priestesses of Persephone at Corinth heard the two goddesses express their intention to accompany Timoleon on his mission to Sicily, and how seers later confirmed their dreams on the basis of a portent at sea. Flower writes as of a chronological sequence of distinct events (or claims), first the dreams - were they simultaneous or sequential, he wonders - and then the portent 
and the seers' confirmation (p. 293), but it is surely more probable that this tale is not as it were an aggregate of live reportage, but a propaganda-story, all of a piece, put together after the fact, with subsequent confirmation by experts of a first group's intimations lending the spurious air of authority that is a favourite device in such tales. An important general point underlies this observation: the fact that some or many Greeks will have credited such a story in its own terms is no reason for us to be uncritical. There are also some unreliable statements in the chapter: the killing of sacrificial animals was by no means invariably done by mageiros rather than priest (see e.g. ThesCRA V, 16), and I am unaware of evidence that a so-called kreonomos (presumably kreanomos) was a standard official who distributed the sacrificial meat (p. 296). On manteis, however, Flower is thoroughly sound, and despite my caveats the chapter as a whole is a good introduction to the subject.

Ralph Anderson contributes a fine chapter on "New Gods", which has a good deal to say about polis authority in religious matters; in study of this aspect of Greek religion, as of some others, the "polis religion" model seems indispensable. Anderson's wellconstructed introductory section is followed by case studies of Pan and Asklepios in Athens and of Sarapis in Egypt - with an excursus on religious change over time and network and post-colonial theory - which exemplify and develop his general observations very well.

Hugh Bowden's chapter on "Impiety" discusses the definition of asebeia and its status as a condition and as an act, with a special focus on atheism (and some critical comment on the adequacy of the "polis religion" model). Two brief case studies of the trial of Andokides and the accusations of atheism against Anaxagoras and Diagoras especially the former - well illustrate his general arguments, and the chapter is recommended to anyone interested in the subject.

Andrej Petrovic's "Sacred Law" begins with an apt and amusing modern comparandum and is lively and instructive in its own terms, but it consists almost entirely of discussion of the limitations of the term "sacred law" and of the criteria of inclusion in the standard corpora and says next to nothing about the actual documents and what they have to tell us about Greek religion. "Von Prott concentrated on the contents, rather than the genre, of the documents he collected" (p. 344), and this chapter's elaboration of fairly straightforward distinctions - which can become wearisome for want of any illustration of why they matter to the interpretation of specific texts rather makes one yearn for Prott's priorities.

Part VI begins with Susan Deacy's "Gods - Olympian or Chthonian?", a helpful orientation to the debate about the nature, limits, and indeed validity of that distinction which also develops an argument that "the relation between the two poles was a fluid one that interrelated with other oppositions" (p. 364). I have myself argued for essentially the same conclusion, as I should acknowledge in saying that Deacy's discussion seems to me eminently sensible.

28 In "Gods - Origins" Carolina López-Ruiz provides a thorough introduction to this central issue, and does so with clarity, accuracy and good judgement: warmly recommended.

29 Gunnel Ekroth's "Heroes - Living or Dead?" is an excellent introduction to central issues in the study of cultic heroes which - typically of Ekroth's work - is also a model of use of the full range of our evidence, archaeological, epigraphical, and literary. Those new to the subject should perhaps be alerted that Ekroth's case study of the cult 
of Pelops at Olympia (which is based on the 2012 paper she cites) is a highly speculative reconstruction based on evidence that can be read very differently.

In his chapter "Dead or Alive?" Emmanuel Voutiras discusses Greek concepts of the soul and the afterlife, necromancy, conjuration of souls, the restless dead and ghosts. Despite some dubious statements - the claim, for example, that the heroes whom Aristophanes fr. $322 \mathrm{KA}$ describes as stewards of ills and benefits "are manifestly revenants" (p. 402)-and what seems to me excessive readiness to regard any and all notions and tales about the underworld as "widespread popular beliefs" (p. 404), this is a very helpful introduction.

Giulia Sfammeni-Gasparo's "Daimonic Power" is a useful study of an important but enigmatic aspect of Greek religion and, especially, of philosophical 'daemonology'. There are some obscurities in the English of this chapter, which has not been edited with adequate care.

Part VI concludes with Ivana Petrovic's "Deification - Gods or Men?", an admirably lively account of Hellenistic ruler-cult and its antecedents which illustrates its points by a series of well-chosen texts and provides a good, brief survey of scholarly trends and debates. The "polis religion" model proves its usefulness here as in some other contributions.

Part VII begins with Henk Versnel on "Prayer and Curse", a characteristically learned, incisive and vigorous exposition. Versnel manages to discuss these central matters including the question of developments over time - both reliably and provocatively; he is particularly sharp on the futility of classifying prayers as religion but curses as "magic". Here again there are lapses in editing, e.g. "loudly" in connection with prayer should doubtless be "aloud" (p. 448). This is one of the best pieces in the volume and urgently recommended.

Fred Naiden's discussion of sacrifice is vigorous and provocative, but readers should be very wary. At the end of the chapter, for example, the interpretations of Burkert and Vernant are assimilated to Christian preoccupations (sin and salvation respectively), which is wildly exaggerated in the case of Burkert - "Jesus' sacrifice is infallible, voluntary, and unique, three more parallels between Christianity and Burkert's view of sacrificial ritual" (p. 473) - and completely arbitrary in the case of Vernant. To claim that "if sacrifice expresses guilt, as with Burkert, or solidarity, as with the French scholars, it expresses universal human attitudes or needs, and so it ought to exist everywhere" (p. 473) is a manifest non-sequitur, as though one were to claim that pledging allegiance to the flag, since it is an expression of the universal need for solidarity, ought therefore to exist everywhere. Naiden's polemic too often transforms what are at bottom reasonable criticisms of both interpretations into caricature and distortion of this kind. Many scholars will feel that Naiden's argument for the centrality of "decorum" - an aesthetic aspect of sacrifice - is also exaggerated. The phrase hôs kallista occasionally expresses the aim of laying on a great festival - in all its aspects, not merely the sacrificial - "as splendidly as possible", but there is no justification for treating the phrase as a terminological "standard of sacrifices" (p. 469), let alone for setting up a contrast between "sacrifice hôs kallista" and "sacrifice kata ta patria" (p. 470), which is simply a false dichotomy.

Sarah Iles Johnston's chapter on oracles and divination is a helpful introduction, based largely on her 2008 book. There is a further example here of a surprising error that should not have survived editing: Prometheus' trick to favour mortals in the division of 
sacrificial meat does not play anything like the central role in Prometheus Bound which Johnston attributes to it (p. 477-478).

Verity Platt's lively and provocative discussion of epiphany likewise draws on her prior work. Some of her interpretations are questionable. She argues, for example, that when in the Homeric Hymn to Aphrodite Anchises senses that the disguised Aphrodite is not a maiden and names five goddesses who she might be, this is an attempt to "avoid any impiety by greeting the goddess with multiple names (as in kletic hymns)" (p. 494), but I know of no evidence that it was impious to address a divinity by a single name and the obvious explanation - that Anchises sensed she was a goddess but, because of her disguise, could not tell which goddess - is surely the right one. One might also suggest that epiphanies are so common in aitia of cult foundations not because subsequent, cultic contact with the divine was perceived as in any sense comparably direct but precisely because it was so radically dissimilar, so mediated and indirect, that the foundational justification of an ultimate epiphanic experience in illo tempore was wanted. The same kind of consideration also perhaps accounts for the "reticence" of Greek texts about epiphanic experience (p.500). Readers should approach Platt's chapter critically, but they will find in it much nourishing food for thought.

Healing cults are discussed by Fritz Graf, who gives special attention to the healing inscriptions from Asklepieia, the confession-inscriptions from Phrygia, and to "epidemics and purification". This is an excellent introduction, anchored throughout in quotation of apt and interesting evidence.

Part VIII begins with Sarah Hitch's "From Birth to Death: Life-Change Rituals", a thoughtful account reflecting recent doubts about broadly 'structuralist' approaches to so-called initiation rituals, particularly those of the Spartan agelai and of Athenian ephebes. Hitch's chapter rightly questions the cogency and applicability of the term 'initiation' and helpfully alerts readers to the wide range of interpretations to which the rites she discusses are open.

Jan-Mathieu Carbon contributes a fine chapter on "Ritual Cycles: Calendars and Festivals" which includes two attractive and illuminating case studies, one relating the sacrificial calendar of Mykonos to the seasonal rhythms of fishing, farming, and politics, and a second discussing the festival of Zeus Sosipolis and the Isiteria festival at Magnesia-on-the-Maeander with particular reference to their relationship to social structures.

Radcliffe G. Edmonds III argues in "Imagining the Afterlife", contrary to the persistent view that more active (e.g. 'Orphic') visions of the afterlife displaced the paler 'Homeric' version, that both kinds of view co-existed throughout the course of Greek antiquity and "should be understood as jostling for authority in particular situations" (p. 551). It is a persuasive argument, well illustrated by discussion of the 'Orphic' gold tablets, the mysts in Aristophanes' Frogs (even if here the distinction between 'belief' and artistic representation is ignored), and Plato's "thinking with" myths of the afterlife, and Edmonds rightly emphasises the persistence of central elements of imagery and myth in conceptually very various notions of the nature of the afterlife.

41 The volume concludes with Part IX, "Beyond?", which comprises chapters on religion in Magna Graecia and in the region of the Cimmerian Bosporus, on ancient near eastern influence, on Graeco-Egyptian religion, and on religion in Greek Bactria and India, and concludes with a comparative chapter on China. My own expertise runs very thin in most of this section. The first two chapters make important points well: Gillian 
Shepherd emphasises the various ways in which the religion of Magna Graecia is no mere duplicate of that of the mainland; Maya Muratov brings out how over several centuries the Greek settlers of the Bosporan kingdom were minimally influenced by the native religion. "The Ancient Near East" by Jan N. Bremmer is a helpful, welldocumented survey of work on this very important subject which illustrates various kinds and routes of influence with well-chosen, up-to-date case studies; a thoroughly reliable and interesting introduction. Kathrin Kleibl's chapter "Greco-Egyptian Religion" is another sound and up-to-date introductory study, which helpfully discusses in turn the key individual gods, cult places and rites, and finally the mysteries and worshippers and cult personnel. Kleibl packs a great deal into the brief span of her chapter, striking an excellent balance between Realien and the conceptual side. Rachel Mairs discusses the religious life of Greeks in Bactria and India. This is a compelling account of the interaction of religious traditions; Mairs manages to be both judicious and fascinating. Lisa Raphals's chapter "China and Greece: Comparisons and Insights" rounds off the volume with comparative studies of cosmogony and cosmology, gods and humans, and divination. The Chinese side of this chapter is far beyond my expertise, but I would observe that Raphals tends to see general comparative issues very much through the lens of divination (the subject of her most recent monograph), which can seem rather limiting, and one could wish that her focus on 'big picture' concepts were leavened with more illustrative detail.

\section{AUTHORS}

\section{SCOTT SCULLION}

Worcester College, Oxford 